\title{
Nilai Budaya Masyarakat Suku Sasak yang Tercermin dalam Lelakaq
}

\author{
Safoan Abdul Hamid*)
}

\begin{abstract}
Abstrak
Masyarakat suku Sasak di Pulau Lombok, Provinsi Nusa Tenggara Barat, dikenal kaya akan berbagai karya sastra daerah. Salah satu jenis karya sastra daerah yang berkembang dalam masyarakat suku Sasak ialah lelakaq atau pantun berbahasa Sasak. Lelakaq memiliki fungsi sosial yang cukup signifikan terutama sebagai media untuk menyampaikan pesan dan nilainilai etika dan budaya. Tulisan ini bertujuan untuk mengungkapkan nilai-nilai budaya masyarakat suku Sasak yang tercermin dalam lelakaq yang terkait dengan hakikat hidup, hakikat hubungan manusia dengan sesama, dan hakikat karya.

Tulisan ini disusun berdasarkan hasil penelitian lapangan di beberapa lokasi di Pulau Lombok yang diyakini masih berkembangnya lelakaq tersebut. Data kesastraan berupa lelakaq dan informasi terkait nilai budaya yang terkandung di dalamnya dikumpulkan dengan menggunakan teknik wawancara mendalam. Data yang terkumpulkan kemudian dianalisis menggunakan metode deskrtiptif dan semiotik.

Hasil analisis data menunjukkan bahwa sebagai salah satu jenis karya sastra sekaligus foklor yang dimiliki oleh masyarakat suku Sasak, lelakaq berisi berbagai muatan nilai budaya yang mencerminkan nilai budaya masyarakat pendukungnya. Nilai budaya tersebut terdiri atas hakikat hidup, hakikat hubungan manusia dengan sesama, dan hakikat karya. Berbagai mutan nilai budaya tersebut secara implisit dan ekplisit terkandung baik dalam sampiran dan isi lelakaq
\end{abstract}

Kata kunci: lelakaq, nilai budaya, masyarakat suku Sasak

\section{Pengantar}

Karya sastra tidak terlahir dari kekosongan budaya (Rahman dkk, 2003:78). Dalam karya sastra dapat digali nilai budaya masyarakat pendukungnya karena melalui karya sastra seorang pengarang mengungkapkan pikiran, perasaan, dan kejadian-kejadian yang ada di

\footnotetext{
* ) Sarjana Pendidikan, Pembantu Pimpinan pada Kantor Bahasa Provinsi NTB
} 
sekitarnya. Djamaris (1993:1--2) mengemukakan bahwa melalui karya sastra nusantara, masyarakat Indonesia mengenal nilai-nilai budaya nenek moyang mereka.

Salah satu karya sastra daerah yang berkembang dalam masyarakat suku Sasak di Pulau Lombok Provinsi Nusa Tenggara Barat ialah lelakaq atau pantun berbahasa Sasak. Sebagaimana umumnya pantun, lelakaq terdiri dari empat baris. Dua baris pertama terdiri dari sampiran dan dua baris yang terakhir terdiri dari isi lelakaq. Lelakaq biasanya memiliki rima a-a-a-a, a-b-a-b, dan a-a. Sedangkan dari segi jumlah kata, kebanyakan lelakaq terdiri empat kata dalam tiap barisnya. Lelakaq berfungsi sebagai media untuk menyampaikan pesan-pesan moral, nasehat, keagamaan, dll. Karena itu dikenal istilah lelakaq penyelamor (penghibur), lelakaq kasmaran, lelakaq tuduh, lelakaq sindiran, dan lelakaq agama. Lelakaq biasanya dibaca secara berbalas antara muda-mudi atau sesama orangtua pada waktu panen padi, sebagai penyemangat dalam bekerja dan sebagai media bagi muda-mudi untuk meyampaikan isi hatinya. Lelakaq juga biasa dinyanyikan yang dikenal dengan istilah ngayaq. Terkadang lelakaq dilantunkan sebagai pengiring dalam melakukan suatu pekerjaan, mengisi waktu kosong, penghibur di kala susah, dsb. (Ensiklopedia Sastra Daerah, 2008:42--43). Secara sosial lelakaq memiliki fungsi pergaulan yang kuat dan sebagai alat penguat penyampaian pesan. Penggunaan lelakaq berfungsi memperhalus pemakaian bahasa sehingga pesan yang disampaikan lebih mengena, terutama apabila lelakaq tersebut berisi berbagai nilai-nilai yang bisa dijadikan acuan hidup.

Tulisan ini bertujuan untuk mendeskripsikan nilai-nilai budaya yang tercermin dalam lelakaq yang berkaitan dengan masalah hakikat hidup, hakikat hubungan manusia dengan sesama, dan hakikat karya. 
Beberapa kajian yang relevan dengan tema karya sastra dan budaya masyarakat pendukungnya telah ditulis oleh beberapa peneliti. Mar'i, dkk. (1997) menulis tentang Resepsi Masyarakat Lombok Terhadap Folklor Lisan Sasak Lelakaq. Aswadi (1999) pernah meneliti tentang Dongeng Etnis Sasak dan Aspek Pendidikan Lingkungan Hidup. Tim Proyek Penelitian Bahasa dan Sastra Indonesia dan Daerah Jakarta pernah mendokumentasikan berbagai karya sastra daerah di Pulau Lombok yang salah satunya adalah lelakaq. Hidayat (2006) menulis tentang berbagai bentuk dan jenis karya sastra daerah yang berkembang di pulau Lombok. Namun kajian-kajian tersebut sama sekali belum menggali nilai-nilai budaya yang terkandung dalam sastra daerah, terutama lelakaq.

Tulisan ini menggunakan pendekatan sosiologi sastra untuk mengkaji nilai budaya dalam lelakaq. Sosiologi sastra memfokuskan kajiannya pada keterkaitan antara karya sastra dengan kenyataan. Karya sastra dipandang sebagai miniatur sosial untuk menginventarisir kejadian-kejadian yang telah dikerangkakan dalam pola-pola kreativitas dan imajinasi. Kualitas responsif dan representatif, entitas, dan integritas karya sastra di tengah-tengah masyarakat mengandung arti bahwa karya sastra secara keseluruhan mengambil bahan di dalam dan melalui kehidupan masyarakat (Ratna, 2003:35--121). Beragam simbolisasi dalam karya sastra merupakan representasi kehidupan sehari-hari. Namun begitu untuk memaknai suatu karya diperlukan pemaham teks secara lebih luas dan komprehensif.

Junus (dalam Februana, 1994) mengemukakan bahwa yang menjadi salah satu pembicaraan dalam telaah sosiologi sastra adalah karya sastra dilihat sebagai dokumen sosial-budaya. Pendekatan tersebut menurut Rahman dkk (2003:78) bertolak dari anggapan bahwa karya 
sastra tidak lahir dari kekosongan budaya dan pandangan bahwa sastra lisan sebagai "pintu masuk" untuk memahami kebudayaan.

Sementara itu, Sutrisno (2008:25) mengemukakan bahwa dalam sastra, simbolisasi terutama ekspresif dan evualuatif sebagai sistem budaya muncul kentara dalam konteks ide-ide, gagasan, dan nilai norma. Di situ pula nilai bisa ditelusuri lewat kehidupan tokoh-tokohnya, cara penyajiannya, dan pengucapan penulisannya. Hakikat sastra adalah segala apa yang ditulis dalam peradaban atau kebudayaan suatu bangsa. Oleh karena itu, pengkajian nilai budaya dalam lelakaq mempunyai nilai yang cukup signifikan untuk memahami jati diri dan identitas masyarakat suku Sasak.

Pengertian nilai budaya menurut KBBI (2002) adalah konsep abstrak mengenai masalah dasar yang sangat penting dan bernilai dalam kehidupan manusia. Koentjaraningrat (1984:41) mengemukakan bahwa nilai budaya merupakan konsepsi yang hidup dalam alam fikiran warga masyarakat mengenai hal-hal yang dianggap paling bernilai sehingga biasanya berfungsi sebagai pedoman hidup. Menurut kerangka Kluchon, Koentjaraningrat mengemukakan bahwa ada lima masalah pokok dalam kehidupan manusia yaitu (1) hakikat hidup manusia; (2) hakikat dari karya manusia; (3) hakikat dan kedudukan manusia dalam ruang dan waktu; (4) hakikat hubungan manusia dengan alam; dan (5) hakikat hubungan manusia dengan manusia lainnya.

Selain sebagai karya sastra daerah, lelakaq juga tergolong sebagai salah satu foklor lisan yang dimiliki oleh masyarakat suku Sasak. Dalam Kamus Wikipedia, folklor di definisikan sebagai berikut:

"Folklore is the body of expressive culture, including tales, music, dance, legends, oral history, proverbs, jokes, popular beliefs, customs, and so forth within a particular population comprising 
the traditions (including oral traditions) of that culture, subculture, or group."

Folklor adalah suatu bentuk media pengungkapan kebudayaan, diantaranya mencakup cerita rakyat, musik, legenda, sejarah lisan, peribahasan, lelucon, kepercayaan populer, kebiasaan dan berbagai hal dalam suatu masyarakat yang mencakup tradisi (termasuk tradisi lisan) pada suatu kelompok budaya, sub-budaya, atau kelompok.

Folklor memiliki beberapa ciri tertentu yakni: a) penyebaran dan pewarisannya dilakukan secara lisan; b) bersifat tradisional; c) folklor ada dalam berbagai versi atau varian, d) bersifat anonim; e) biasanya mempunyai bentuk berumus atau berpola, $\mathrm{f}$ ) mempunyai kegunaan dalam kehidupan kolektif, f) bersifat pralogis, (h) menjadi milik bersama, (i) biasanya bersifat polos dan lugu (Dananjaya, 1986:3--5).

Data lelakaq dalam tulisan ini dikumpulkan dari beberapa daerah sampel di Pulau Lombok yang diyakini masih berkembang tradisi lelakaq. Pengambilan sampel dilakukan dengan teknik sampel yang bertujuan (purposive sampling) yang dikombinasikan dengan teknik bola salju (snow-ball sampling). Teknik ini menurut Frey (dalam Mulyana, 2002:182) ibarat bola salju dalam menentukan subjek penelitian sampai mencapai "data jenuh" (Endraswara, 2006:206). Pengumpulan data lelakaq dilakukan menggunakan dengan menggunakan teknik percakapan mendalam (in-depth interview) (Fontana dan Frey, 1994:365--366). Untuk menganalisis dan mengungkapkan nilai budaya yang terkandung dalam teks lelakaq, digunakan metode deskriptif dan semiotik. 


\section{Pembahasan}

\subsection{Pengidentifikasian Data}

Pengumpulan data kesastraan berupa lelakaq telah berhasil mengidentifikasi beragam jenis lelakaq, termasuk informasi terkait nilai budaya yang terkandung di dalamnya, dari berbagai daerah sampel di pulau Lombok. Beberapa daerah sampel tersebut antara lain Tanjung (Lombok Utara), Gerung (Lombok Barat), Puyung (Lombok Tengah), dan Tembeng Putik (Lombok Timur). Setelah dilakukan penggolongan berdasarkan jenisnya, ditemukan jenis lelakaq agama, lelakaq nasehat, lelakaq penyelemor (penghibur), lelakaq sindiran, lelakaq tuduh, dan lelakaq kasmaran. Keseluruhan data lelakaq tersebut kemudian direduksi untuk mengidentifikasi lelakaq yang berisi nilai budaya yang terkait dengan masalah hakikat hidup, hakikat hubungan manusia dengan sesama, dan hakikat karya.

\subsection{Nilai Budaya Etnis Sasak yang Tercermin dalam Lelakaq}

\subsubsection{Nilai Budaya yang Berhubungan dengan Hakikat Hidup}

\subsubsection{Sikap Moderat}

Sikap moderat maksudnya selalu menghidari prilaku atau pengungkapan yang ekstrim atau berkecenderungan ke arah dimensi atau jalan tengah (KBBI, 2002). Dari Lelakaq di bawah ini dapat ditangkap pesan tentang sikap moderat:

Ri rincik

Kukelaq gedeng antap

Leq sedi kusisik

Leq tengaq kuangkat

Ri Rincik 
Kurebus daun kacang

Di bagian pinggir kusisir

Yang tengah kuangkat

Lelakaq di atas sangat terkenal dalam masyarakat suku Sasak dan tergolong sebagai lelakaq penghibur. Ungkapan dalam isi lelakaq leq sedi kusisik, leq tengaq kuangkat (yang di pinggir kusisir, yang di tengah kuangkat) mengandung makna filosofis agar kita selalu mengutamakan atau memilih jalan tengah dalam menghadapi berbagai persoalan hidup. Mengambil jalan tengah atau bersikap moderat adalah jalan dan urusan terbaik. Seorang moderat tidak akan memilih atau memihak salah satu diantara dua pihak atau sisi ekstrim. Konsep moderat dalam lelakaq tersebut dapat maknai secara luas ke dalam berbagai aspek kehidupan sehingga menjadi suatu konsep atau pandangan hidup.

\subsubsection{Kesederhanaan}

Dari lelakaq di atas juga dapat digali nilai kesederhanaan. Ungkapan leq sedi kusisik, leq tengaq kuangkat (yang di pinggir kusisir, yang di tengah kuangkat) juga dapat dimaknai sebagai anjuran untuk hidup sederhana. Hidup sederhana maksudnya menjalani hidup sedangsedang saja, yakni menghindari sikap boros, suka menghamburhamburkan uang, atau berfoya-foya. Nilai sederhana juga berarti menghindari sikap kikir, pelit, tamak, dan sikap terlalu merendahkan atau meremehkan diri sendiri baik dalam gaya hidup maupun penampilan fisik. Dengan kata lain, nilai sederhana berarti memilih cara dan gaya hidup yang menghindari dua sikap ekstrim tersebut, yakni dengan memilih jalan tengah, sedang-sedang saja. Contohnya dalam penggunaan uang hendaknya tidak terlalu boros tapi juga tidak terlalu kikir. 
Nilai sederhana juga dapat berarti suatu jalan yang tidak banyak seluk-beluknya atau jalan lurus. Pulau Lombok, yang didiami oleh mayoritas etnis Sasak, berasal dari kata lomboq (bahasa Sasak) yang berarti lurus. Hal ini relevan dengan kondisi empiris orang Sasak yang cenderung masih lugu, polos, dan tidak menyukai jalan hidup yang berliku.

\subsubsection{Keseimbangan}

Ungkapan leq sedi kusisik, leq tengaq kuangkat (yang di pinggir kusisir, yang di tengah kuangkat) juga dapat dimaknai sebagai nasehat untuk menjalani kehidupan dengan penuh keseimbangan dalam segala aspeknya. Sepadan dengan nilai moderat, keseimbangan berarti tidak cenderung kepada salah satu sisi dalam kehidupan. Keseimbangan juga dapat berarti memberikan prioritas yang sama terhadap setiap aspek kehidupan. Konsep keseimbangan salah satunya ditunjukkan dalam prilaku keberagamaan masyarakat Sasak, sebagaimana yang diekspresikan dalam lelakaq berikut:

Lalo peken kanca saodaranta

Beli empaq pinaq dedupaq

Utamayang urusan akheratta

Urusan dunia ndeq ta pada lupa

Pergi ke pasar bersama saudara kita

Beli ikan untuk buat dedupaq

Utamakan urusan akhirat kita

Urusan akhirat jangan kita lupa 
Lelakaq di atas menganjurkan agar dalam menjalankan ajaran agama, terutama agama Islam, hendaknya dengan menjunjung tinggi nilai keseimbangan. Dunia dan akhirat adalah dua alam keniscayaan. Dunia adalah kehidupan sementara sedangkan akhirat adalah alam kehidupan abadi yang menjadi tujuan akhir kehidupan. Kehidupan dunia adalah sebuah perjalanan panjang menuju kebahagiaan di negeri keabadian (akhirat). Prilaku hidup di dunia menentukan nasib di alam akhirat. Konsep yang agung ini hendaknya dipahami secara proporsional yakni dengan mengutamakan keseimbangan antara keduanya. Berbagai aktivitas terkait kedua tahapan kehidupan ini disinergikan di mana salah satunya mendukung yang lainnya. Tidak ada dikotomi antara aktivitas untuk kehidupan dunia dan akhirat, keduanya adalah amal saleh yang bernilai ibadah.

\subsubsection{Keadilan}

Ungkapan leq sedi kusisik, leq tengaq kuangkat (yang di pinggir kusisir, yang di tengah kuangkat) juga mengekspresikan nilai keadilan. Sikap adil berarti tidak memihak kepada salah satu pihak atau memilih jalan tengah. Lelakaq berikut berkaitan dengan nilai keadilan:

Bau kerang leq pelangan

Kayuq nangke jari pageran

Lamun curang leq timbangan

Api nerake jari balesan

Tangkap kerang di Pelangan

Kayu nangka menjadi pagar

Kalau curang dalam timbangan

Api neraka sebagai balasan 
Lelakaq di atas berisi nasehat kepada para pedagang untuk tidak berbuat curang dalam menimbang. Seorang pedagang yang adil tentu tidak akan mengurangi timbangan karena prilaku tersebut dapat merugikan pembeli. Timbangan adalah simbol keadilan. Sikap berat sebelah atau cenderung kapada salah satu pihak adalah salah satu bentuk kezaliman. Timbangan yang benar dapat maknai sebagai implementasi nilai-nilai keadilan dalam setiap ranah kehidupan. Berikut ini adalah sebuah lelakaq yang berkaitan dengan implementasi nilai keadilan:

Daun pakis leq taman sari

Beli sesate leq pelempat

Lamun adil leq anak jari

Waktu mate ndeq serembat

Daun pakis di Taman sari

Beli sate di Pelempat

Kalau adil terhadap anak keturunan

Waktu mati tidak ada beban

Lelakaq di atas berisi implementasi nilai keadilan dalam lingkup keluarga, yakni sikap adil terhadap anak keturunan. Sikap adil terhadap anak keturunan akan mendatangkan kebaikan bagi pelakunya terutama ketika akhir hayatnya. Namun sikap adil dalam konteks ini tidaklah dipahami secara hitam putih. Sikap adil berarti memberikan sesuatu sesuai dengan porsinya. Semua anak keturunan harus diperlakukan dan diberikan harta sesuai dengan keadaan dan umur masing-masing anak tersebut. Menyamaratakan perlakuan dan pemberian bukanlah berarti sikap adil. 


\subsubsection{Mempertahankan Tradisi}

Makna lain yang tersirat dalam isi teks lelakaq leq sedi kusisik, leq tengaq kuangkat yakni nasehat untuk mempertahankan tradisi lama yang masih asli. Tradisi lama harus dipertahankan karena ia merupakan perlambang jati diri dan identitas. Kata leq tengaq (tengah) dalam lelakaq di atas adalah konotasi sesuatu yang masih utuh atau belum terkontaminasi oleh pengaruh luar. Sedangkan sesuatu yang berada di pinggir (sedi) seperti dalam lelakaq leq sedi kusisik (yang tengah kusisir) menunjukkan bahwa yang berada pada posisi pinggir sangat rentan dengan pengaruh luar karena untuk menuju bagian tengah harus melalui bagian pinggir. Oleh karena itu, sebelum bagian yang masih asli ini punah atau mengalami perubahan karena pengaruh luar, sebaiknya segera diangkat dan dilestarikan. Sebuah lelakaq yang relevan dengan pembahasan ini adalah:

Mula kesurah perang Praya

Jangka lauq datang pujut

Sorong serah aji krama

Pusaka laeq masih teturut

Memang mahsyur perang Praya

Dari utara ke selatan Pujut

Adat sorong serah aji krama

Pusaka Sasak yang masih kuat

Lelakaq di atas berisi petuah untuk mempertahankan salah satu tradisi Sasak yang dikenal dengan sorong serah aji krama dalam perkawinan masyarakat suku Sasak. Masyarakat Sasak kaya akan berbagai kearifan lokal dan adat istiadat yang sangat membutuhkan 
perhatian. Mempertahankan tradisi lokal tersebut menunjukkan kebanggaan akan identitas dan jati diri.

\title{
2.2.1.6 Nilai Religiusitas
}

Pinaq rakit leq Punie

Kadu bejukung leq tengaq erat

Timaq nyakit leq dunie

Laguq beruntung leq akhirat

\author{
Buat rakit di Punia \\ Pakai berlayar di tengah sungai \\ Walaupun sengsara di dunia \\ Tapi beruntung di akhirat
}

Lelakaq di atas tergolong sebagai lelakaq agama. Keberadaan lelakaq tersebut berfungsi sebagai pelipur lara bagi mereka yang dalam kehidupan di dunia ini ditakdirkan, terutama dari segi ekonomi, kurang beruntung. Namun hal itu tidaklah membuat hati bersedih kalau masingmasing diri memahami hakikat hidup di dunia. Kehidupan dunia adalah sebuah persinggahan sementara menuju alam keabadian yakni alam akhirat. Kesengsaraan hidup di dunia bukanlah kesengsaraan abadi, bahkan merupakan ujian dari Yang Maha Kuasa. Kebahagiaan di alam akhirat bukan ditentukan oleh banyaknya harta namun ditentukan oleh ketaatan dalam menjalankan agama.

Terciptanya lelakaq ini sangat relevan dengan kondisi sosial masyarakat etnis Sasak yang memberikan perhatian yang cukup besar pada aspek-aspek yang terkait dengan dimensi keagamaan seperti peribadatan dan perayaan hari-hari besar keagamaan. Bahkan Pulau 
Lombok dikenal sebagai Pulau Seribu Masjid karena menjamur masjid di pulau ini. Sementara itu Tuan Guru adalah titik sentrum kharismatik dalam masyarakat Sasak yang berperan sebagai sumber spiritual bagi masyarakat muslim Sasak.

Nilai religiusitas juga ditunjukkan oleh agama selain agama Islam seperti agama Hindu. Umat Hindu di Pulau Lombok juga sangat kuat memegang nilai religiusitas yang ditunjukkan dengan maraknya aktivitas persembahyangan dan perayaan hari-hari besar keagamaan.

\title{
2.2.2 Nilai Budaya yang Berhubungan dengan Hakikat Hubungan Manusia dengan Sesama
}

\subsubsection{Persaudaraan}

\author{
Daun bone jari olah-olah \\ Pinaq urap sedaq terong \\ Ku bedoe batur saq solah \\ Maraq idap besemeton
}

\author{
Daun bone untuk membuat olah-olah \\ Buat urap campur terong \\ Kupunya sahabat yang bagus \\ Merasa seperti bersaudara
}

Orang Sasak biasanya menyebut orang lain, baik yang sudah lama atau baru dikenalnya, dengan panggilan semeton/ton yang maksudnya saudara. Penggunaan panggilan semeton tersebut dilakukan karena orang Sasak manganggap orang lain adalah saudara mereka. Hal ini menunjukkan betapa luasnya konsep 'persaudaraan' dalam masyarakat Sasak. Persaudaraan tidak hanya dibatasi oleh pertalian darah. 
Sebagaimana digambarkan dalam lelakaq di atas, teman atau sahabat yang baik juga dianggap sebagai saudara, seperti halnya saudara kandung. Bahkan ikatan emosional yang tumbuh dalam ikatan persahabatan sejati terkadang melebihi ikatan saudara kandung.

Luasnya nilai persaudaraan dalam masyarakat Sasak menjadi salah satu potensi untuk melanggengkan kehidupan yang damai mengingat semua orang dan teman-teman yang baik dianggap sebagai saudara.

\subsubsection{Persahabatan}

Lalo ngerakat sambil tepasang buwu

Tune licin leq dalem loang timbangan

Lamun besahabat ndeq pandang bulu

Sugih miskin pade doang

Pergi ngerakat ${ }^{1}$ sambil pasang bubu ${ }^{2}$

Tuna licin dalam lubang timbangan

Kalau berteman tidak pandang bulu

Kaya miskin sama saja

Bejukung ngadu perau

Perabot leq atas berugaq

Beruntung yaq tepayu

Bersahabat yaq tepade lupaq

\footnotetext{
${ }^{1}$ Tangkap ikan menggunakan jaring

2 tempat ikan yang dipakai ngerakat
} 
Pergi merakit menggunakan perahu

Peralatan di atas berugaq

Berjodoh kita tidak dinasibkan

Bersahabat jangan kita lupakan

Dalam masyarakat Sasak, kata sahabat sering merujuk kepada semua orang yang sudah saling mengenal, baik dalam jangka waktu lama maupun sebentar. Dalam lelakaq tersebut digambarkan bahwa persahabatan sejati tidak mengenal batas status sosial dan kekayaan. Kepada semua orang kita layak untuk menjalin tali persahabatan. Hubungan cinta muda-mudi yang terputus pun tidak semestinya memutuskan hubungan persahabatan mereka. Status yang semula disebut beberayean (pacaran) telah berubah menjadi persahabatan biasa.

\subsubsection{Berbakti kepada kedua Orang Tua}

Musim panas sekat gati araq aiq

Dateng angin jangka layu kekayonan

Endeq piwal pangeran pade matiq

Sai bangge tentu salaq kejarian

Musim panas begitu sulit mendapatkan air

Angin berhembus mengeringkan pepohonan

Jangan melawan orang tua tapi taatlah

Siapa durhaka tentu akan menemui nasib jelek

Puncak tertinggi hubungan antara manusia dengan sesama terletak pada kualitas hubungan dengan kedua orang tua. Orang tua adalah orang yang paling dekat dan berjasa karena telah melahirkan, 
membesarkan, dan mendidik kita. Begitu mulia kedudukan orang tua sehingga dalam lelakaq di atas ayah atau ibu disebut sebagai pangeran. Istilah ini digunakan untuk menghormati dan memuliakan orang tua. Berbuat baik kepada orang tua tentu akan mendatangkan kebaikan bagi diri sendiri di dunia maupun di akhirat kelak. Tapi sebaliknya durhaka kepada keduanya akan mendatangkan keburukan, seperti digambarkan dalam kedua ba'it lelakaq berikut:

Kelaq nangke kelaq komak

Toloq sie leq sempare

Ndaq bangge leq inaq amaq

Laun idup jari sengsare

Rebus nangka rebus buncis

Taruh garam di beranda

Jangan durhaka sama ibu bapak

Nanti hidup jadi sengsara

Ngunjal geres kadu bakaq

Kembang cempake kembang lili

Dendeq girang muni keras leq inaq

Sengaq sino dose ndeq teampuni

Angkut pasir pakai bakul

Bunga cempake bunga ilir

Jangan suka berkata kasar pada ibu

Sebab itu dosa yang tidak terampuni 
Salah satu cara berbakti kepada orang tua yakni dengan bertutur kata lemah-lembut kepada keduanya, tidak berkata keras, apalagi membentaknya. Durhaka kepada orang tua tergolong sebagai dosa besar.

Diantara kedua orang tua, ibulah yang lebih dekat dengan kita secara emosional. Ketidakhadiran ibu biasanya terasa lebih berat dibandingkan ketiadaan ayah. Seorang anak yang ditinggal mati oleh ibunya disebut sebagai anaq ki(w)oq (piatu). Anaq ki(w)oq biasanya lebih terlantar dibandingkan anak yatim. Bahkan istilah anaq ki(w)oq pun kerap digunakan untuk menyebut seorang anak yang begitu telantar/tidak terurus meskipun kedua orang tuanya masih hidup. Ratapan seorang anaq ki(w)oq diekspresikan dalam lelakaq berikut ini:

Yaq ku pepit inaq talin timbah

Pinaq bale isiq kayuq odang

Mulen nyakit den araq inaq

Ndaraq bae taoq ku nongaq
Akan ku lipat tali sumur
Buat rumah pakai kayu odang
Memang sengsara tidak memiliki ibu
Tidak ada tempatku menengadah

Dalam lelakaq di atas ibu digambarkan sebagai tempat untuk menengadah (nongaq). Kata nongaq dapat bermakna sebagai ketergantungan seorang anak kepada ibunya hanya kepada ibulah seorang anak mengharapkan kasih sayang, bimbingan, dan pendidikan yang baik. 


\subsubsection{Gotong royong}

Lekaq-lekaq meta kembang cempake

Mete kembang sino laguq mauq jagung

Lamun na araq dengan kena bencana

Becat-becat si pada betulung

Jalan-jalan cari bunga cempaka

Namun jagung yang didapat

Jika ada orang terkena bencana

Cepatlah memberi pertolongan

Lelakaq di atas menggambarkan budaya gotong royong sebagai sebuah tradisi yang mengakar dalam masyarakat suku Sasak. Gotong royong memiliki makna bekerja bersama-sama untuk melakukan suatu pekerjaan. Dalam bahasa Sasak gotong-royong sepadan dengan kata beriuk tinjal atau secara harfiah berarti bersama-sama mendendang, artinya jika suatu pekerjaan dikerjakan secara bersama-sama maka pekerjaan tersebut lebih cepat selesai dan hasilnyapun lebih baik.

Secara empiris, budaya bergotong-royong dalam masyarakat Sasak sangat menonjol terutama dalam pembangunan dan rehabilitasi tempat atau fasilitas yang berkaitan dengan aktivitas keagamaan. Antusiasme masyarakat suku Sasak begitu tinggi dalam bergotongroyong untuk membangun masjid, mushala, madrasah/pondok pesantren, atau semua tempat yang terkait dengan kegiatan keagamaan. Selain itu, gotong-royong juga sudah biasa dilakukan untuk membantu pembangunan rumah penduduk yang kurang mampu. 


\subsubsection{Musyawarah}

Jiga lebaran batur

Pada miaq ketupat

Munjiga gotong royong oe batur

Bagusan tan mufakat

Jika lebaran tiba kawan

Ayo kita Buat ketupat

Dengan gotong royong kawan

Baguslah dalam bermufakat

Musyawarah berarti pembahasan bersama atau rembuk untuk mencapai mufakat dalam penyelesaian atas suatu masalah. Secara substansi bermusyawarah juga salah satu bentuk 'gotong-royong' karena suatu masalah (pekerjaan) dipecahkan secara kolektif. Kedekatan makna tersebut ditunjukkan dalam lelakaq di atas yang intinya memberikan suatu nasehat akan arti penting musyawarah untuk mencapai mufakat. Jika suatu masalah diselesaikan secara gotong-royong atau melibatkan banyak orang maka pemecahannya akan lebih cepat dan hasil yang dicapai pun lebih baik dan berterima. Dalam masyarakat suku Sasak setiap permasalahan umumnya diselesaikan dengan musyawarah (sangkep) dan apapun hasilnya bersifat mengikat.

\subsubsection{Nilai Budaya yang Berhubungan dengan Hakikat Karya}

\subsubsection{Berilmu}

Lamun side gen lalo pano

Perlu side jauq tambah

Lamun side jaq uah tao

Tentu side gen jari molah 
Kalau engkau pergi ke sawah

Engkau perlu membawa cangkul

Kalau engkau sudah berpengetahuan

Tentu hidupmu menjadi mudah

Lelakaq di atas tergolong sebagai lelakaq nasehat. Pesan yang disampaikan adalah penghargaan yang tinggi terhadap ilmu dan orang yang berilmu. Untuk bisa bekerja dan mencapai hasil yang bagus seseorang haruslah dibekali dengan ilmu yang memadai. Teks lelakaq gen jari molah (Tentu hidupmu menjadi mudah) maksudnya orang yang berilmu/berpendidikan hidupnya menjadi lebih mudah dan lebih dekat menuju kesuksesan. Dalam masyarakat Sasak penghargaan tertinggi diberikan kepada orang yang menguasai ilmu agama. Maka tidak mengherankan sosok Tuan Guru dan pemuka agama menjadi begitu dihormati. Hal ini tidak terlepas dari realita bahwa masyarakat suku Sasak adalah masyarakat yang religius. Penghargaan selanjutnya adalah kepada orang yang berpengetahuan dalam bidang-bidang lainnya sepanjang memperlihatkan prilaku yang baik dalam masyarakat.

\subsubsection{Kerja Keras}

Beli beras leq sambelie

Dendeq lupaq jauq kepeng

Lamun ne mélé idup mulie

Pacu-pacu pete kepeng

Beli beras di Sambelia

Jangan lupa bawa uang

Kalau mau hidup mulia

Tekunlah mencari uang 
Lelakaq di atas berisi anjuran untuk bekerja keras. Раси-раси pete kepeng (tekunlah mencari uang) maksudnya anjuran untuk bekerja keras. Dalam masyarakat suku Sasak pergi "mencari uang" maksudnya pergi bekerja. Seorang pemuda yang terkenal sebagai pekerja keras disebut kanak pacu (orang yang tekun). Kata pacu terkadang juga digunakan merujuk kepada orang yang rajin beribadah seperti rajin shalat, puasa, dan sebagainya. Jadi apabila ada yang mengatakan, (n)ie kanak pacu (ia anak yang tekun). Maknanya dapat berarti ia anak yang rajin ibadah (walaupun bukan pekerja keras), tetapi dapat juga bermakna ia anak yang pekerja keras (walaupun tidak rajin beribadah). Sejalan dengan lelakaq di atas, dalam masyarakat kemuliaan juga disematkan kepada orang yang suka bekerja keras sebagaimana halnya kepada orang yang menguasai ilmu.

\subsubsection{Pantang Menyerah}

Ojok Bali ngadu kapal

Kapal terdampar leq pantai Kuta

Lamun araq pegawean siq gagal

Ndaqda girang pada putus asa

Pergi ke Bali memakai kapal

Kapal terdampar di pantai Kuta

Jika ada pekerjaan yang gagal

Jangan anda berputus asa

Dua baris sampiran dalam lelakaq di atas Ojok Bali ngadu kapal/ kapal terdampar leq pantai Kuta (Pergi ke Bali memakai kapal / Kapal terdampar di pantai Kuta) menggambarkan sebuah perjalanan menuju pulau Bali. Biasanya perjalanan orang Sasak ke Bali ialah untuk bekerja 
karena disana konon lebih banyak lapangan pekerjaan. Kapal yang terdampar di Pulau Kuta dimaknai sebagai kegagalan dalam melakukan usaha atau kerja.

Bagian sampiran terkait dengan isi lelakaq yang memberikan nasehat agar kita tidak cepat menyerah apabila mengalami jalan buntu atau kegagalan dalam setiap usaha yang kita kerjakan. Kegagalan adalah cambuk dan merupakan keberhasilan yang tertunda, sedangkan sikap putus asa adalah kegagalan total dari suatu usaha. Sikap optimis hendaknya selalu ditunjukkan untuk mengiringi setiap langkah.

\subsubsection{Perspektif Gender dalam Konteks Kekaryaan}

Kedit lime meper gunung

Baleq te baleq bangket

Jergit ime apeq punjung

Pemongkaq bi mataq ketalet

Burung lima menepi ke gunung

Rumahku rumah sawah

Tangan lincah tata gelung rambut

Namun perikmu matang bawah

Lelakaq di atas tergolong sebagai lelakaq sindiran, yakni sindiran kepada seorang perempuan yang sehari-harinya hanya pandai bersolek namun tidak bisa memasak. Secara implisit lelakaq tersebut menggambarkan peran kaum perempuan dalam konteks kekaryaan. Dalam masyarakat Sasak seorang perempuan dituntut memiliki peran terkait dengan keberadaan dirinya dalam lingkungannya, yakni untuk berkarya dan memiliki keterampilan. Minimial seorang perempuan harus 
menguasai keterampilan dalam menjalankan tugas-tugasnya dalam rumah tangga. Adapun perempuan yang tidak mampu berkarya yang disimbolkan dengan ungkapan hanya sibuk "apeq punjung" namun "pemongkaq bi mataq ketalet" kurang dihargai oleh masyarakat.

Seorang istri atau perempuan sejati dalam masyarakat Sasak memiliki peran yang tidak kalah dengan kaum laki-laki dalam berkarya. Salah satu fenomena dalam masyarakat Sasak ialah seorang perempuan pengantin baru, bahkan pada hari pertama di rumah sang suami, harus menunjukkan diri sebagai seorang perempuan pekerja keras. Kalau tidak, ia akan menjadi bahan gunjingan wanita-wanita di sekitarnya dan mendapat stigma sebagai perempuan malas. Pagi-pagi sekali ia harus sudah menyapu halaman rumah, membersihkan perabot, dan sebagainya. Kesimpulannya lelakaq di atas mengandung makna terkait dengan perspektif gender yang menempatkan posisi wanita sepadan dengan kaum laki-laki dalam aspek kekaryaan.

\section{Penutup}

Lelakaq adalah pantun berbahasa Sasak. Lelakaq tergolong sebagai salah satu jenis sastra daerah, sekaligus sebagai salah satu folklor lisan yang berkembang dalam masyarakat suku Sasak di Pulau Lombok Provinsi Nusa Tenggara. Lelakaq memiliki fungsi sosial sebagai perekat dalam pergaulan dalam masyarakat dan sebagai media penyampaian pesan dengan pola penggunaan bahasa yang khas. Keberadaan lelakaq begitu penting karena dari lelakaq tersebut dapat digali nilai budaya masyarakat pendukungnya.

Nilai-nilai budaya masyarakat suku Sasak yang dapat digali dari lelakaq tersebut adalah: 
a. Hakikat hidup, nilai budaya yang menunjukkan hakikat hidup antara lain 1) moderat; 2) kesederhanaan; 3) keseimbangan; 4) keadilan; 5) mempertahankan tradisi; dan 6) nilai religiusitas.

b. Hakikat hubungan manusia dengan sesama, terdiri dari: 1) persaudaraan; 2) persahabatan; 3) berbakti kepada orang tua; 4) gotong royong; dan 5) musyawarah

c. Hakikat karya, nilai budaya yang menunjukkan hakikat karya antara lain 1) kerja keras; 2) pantang menyerah; dan 3) perspektif gender dalam konteks kekaryaan.

Berbagai nilai budaya yang digali dari lelakaq tersebut mencakup nilai-nilai yang dapat menjadi pedoman hidup sehari-hari. Oleh karena itu, keberadaan karya sastra ini perlu mendapat perhatian kita bersama, salahnya satu dalam bentuk pengkajian dan tulisan yang mengungkapkan nilai-nilai positif yang terkandung di dalamnya.

\section{Daftar Pustaka}

Danandjaja, James. (2002). Folklor Indonesia: Ilmu Gosip, Dongeng, dan Lain-lain. Jakarta: PT Grafiti Pers.

Djamaris, Edward. (1990). Menggali Khazanah Sastra Melayu Klasik. Jakarta: Balai Pustaka.

Endraswara, Suwardi. (2006). Metodologi Penelitian Kebudayaan. Yogyakarta: Gadjah Mada University Press.

Hidayat, Rachmat. (2006). Distribusi dan Pemetaan Bentuk dan JenisJenis Karya Sastra yang Tumbuh dan Berkembang Pada Masyarakat Tutur Bahasa Sasak di Pulau Lombok.

Koentjaraningrat. (1984). Kebudayaan, Mentalitas, dan Pembanguan. Jakarta: Gramedia. 
90 Mabasan - Vol. 3 No. 2 Juli-Desember 2009: 66--90

Rakhman, Muhammad Arif dkk. (2003). Sastra Interdisipliner: Menyanding Sastra dan Disiplin Ilmu Sosial. Yogyakarta. Yogyakarta: CV. Qalam.

Ratna, Nyoman Kutha. (2004). Teori, Metode, dan Teknik Penelitian Sastra. Yogyakarta: Pustaka Pelajar. . (2007). Estetika Sastra dan Budaya. Yogyakarta. Pustaka Pelajar.

Saparie, Gunoto. (2007). Luasnya Wilayah Sosiologi Sastra dalam http://www.suarakarya-online.com/news.html?id=168818 diakses 18 November 2008.

Tim Proyek Penelitian Bahasa dan Sastra Indonesia dan Daerah. (1986). Sastra Lisan Sasak. Jakarta: Pusat Pembinaan dan Pengembangan Bahasa.

Tim Redaksi. (2002). Kamus Besar Bahasa Indonesia. Jakarta: Balai Pustaka. 